\title{
The Kaingang-Austronesian Relationship Hypothesis: Evidence from Kinship Terminology
}

\author{
Vladimir Pericliev \\ Bulgarian Academy of Sciences
}

\begin{abstract}
The Kaingang language family comprises two closely related languages, Xokleng and Kaingang, spoken in south-eastern Brazil, on the Atlantic, and the Austronesian family includes a large number of languages, covering a vast area in the Pacific. Our previous investigations reveal significant similarities between the Kaingang and Austronesian language families in both grammar and lexicon, suggesting the existence of phylogenetic affiliation between these language families. This unexpected hypothesis, having important implications for linguistics and other related disciplines, however, requires further severe tests for its corroboration. In this paper, I present an in-depth analysis of the parallels in the kinship terminologies of these two families. It is shown that Kaingang and Austronesian kin terms resemble substantially both in their forms and in their structural meanings (= kin term patterns) and this result
\end{abstract}

\footnotetext{
Vladimir Pericliev

Institute of Mathematics and Informatics, bl. 8, Bulgarian Academy of Sciences 1113 Sofia, Bulgaria

Phone: (++3592) 9792877; Email: peri@math.bas.bg
}

Received June 29, 2011; Revised August 31, 2011; Accepted September 9, 2011. 
104 The Kaingang-Austronesian Relationship Hypothesis

provides strong support for the hypothesis. The occurrence of putative kin term cognates between Kaingang and Proto-Oceanic, such that do not have antecedents in the earlier Proto-MalayoPolynesian or Proto-Austronesian stages of Austronesian, suggests an Oceanic origin of Kaingang.

Keywords: kaingang-austronesian relationship hypothesis, contacts between oceania and south america, language prehistory and classification, languages and migrations

\section{Introduction}

The Kaingang language family, comprises two closely related extant languages Xokleng (also called Aweikoma) and Kaingang, and a third member, Ingain, now being extinct. The Kaingang languages are spoken by about 22,000 hunter-gatherers (Rodrigues 1999), who presently reside in south-eastern Brazil, spread out over the states of Santa Catarina, São Paulo, Paraná, and Rio Grande do Sul. The Kaingang languages were considered as an independent family by earlier scholars, but were later argued to belong to the $\mathrm{Ge}$ family (cf. Davis 1966). No external relationship of the Kaingang languages outside of Ge, or Amerindian more generally, has so far been suggested. Their language and culture is quite distinct from the neighboring Guaraní. In population genetics, it was found by (Cavalli-Sforza et al. 1994: 323-4) that the Macro-Ge people are the worst outliers in drawing a phylogenetic tree of 23 American tribes, grouped according to linguistic criteria.

Our previous investigations (Pericliev 2006, 2007, 2009, 2010) have shown unexpected similarities between the Kaingang family and the widely spread Austronesian language family, covering a vast area from Madagascar to the west and Easter island to the east, and from Hawaii to the north and New Zealand to the south. Significant similarities between the two language families were found in both 
structural features and lexicon, leading to the positing of the hypothesis of the existence of a historical (probably phylogenetic) relationship between Kaingang and Austronesian. Section 2 summarizes this research, thus providing a background for the following discussion. Section 3 gives parallels between the shapes of kin terms in both language families, showing a close fit by assuming a couple of natural and well-supported phonological processes. In Section 4, I show similarities in the semantic structure (or, kin term patterns) of Kaingang and Austronesian, and Section 5 is a discussion of the results obtained so far and how to interpret them. Here, it is suggested that the Kaingang family probably originates from the Oceanic branch of Austronesian, owing to the existence of putatively cognate kin terms with Proto-Oceanic, which have not been registered in the earlier Proto-Malayo-Polynesian or Proto-Austronesian stages of the language.

\section{Summary of Previous Research}

Our previous studies on the similarities between Kaingang and Austronesian (Pericliev 2006, 2007, 2009, 2010) encompass various aspects of the languages, which are briefly sketched below.

\subsection{Structural Similarities}

The Kaingang languages possess a number of structural features that have been proposed by Klamer (2002) as diagnostic for membership in the Austronesian family and serving to demarcate a language that is Austronesian from a language which is not. The phonologically diagnostic features, shared by Kaingang and Austronesian, include e.g., the presence of prenasalized stops, preference for $\mathrm{CVCV}$ roots $(\mathrm{C}=\mathrm{Consonant}, \mathrm{V}=\mathrm{Vowel})$, with the correlated dispreference for $\mathrm{CC}$ clusters and preference for open 
106 The Kaingang-Austronesian Relationship Hypothesis

syllables, especially, at the end of words, paragogic vowels, and so on. The grammatically diagnostic features include shared traits like verbs for emotional states expressed as verb + body part, numerals acting like verbs, absence of passive constructions, presence of the distinction alienable vs. inalienable nouns, use of parallelism, active vs. stative verbs, and so on.

\subsection{Lexical Similarities I: Statistical Test}

In lexicon, statistically significant resemblances can be observed in pair-wise computational comparisons between 100-item basic vocabulary wordlists of Xokleng and Kaingang on the one hand, and the reconstructed Proto-Austronesian and five major extant Austronesian languages (Tagalog, Malay, Fijian, Samoan, and Hawaiian) on the other hand. Standard similarity criteria for matching two word forms have been used in the experiment: generally, two identical consonants, or an identical consonant and a vowel plus a phonetically "similar" consonant. The method (which follows closely the received method of Oswalt 1991) has been tested against pairs of languages with well understood relationships, both positive and negative. All comparisons were significant at levels shown below (with accuracy up to four decimal places).

(1)

\begin{tabular}{|l|c|c|c|c|c|c|}
\hline & Proto-AN & Tagalog & Malay & Fijian & Samoan & Hawaiian \\
\hline Xokleng & 0.0000 & 0.0000 & 0.0002 & 0.0022 & 0.0003 & 0.0000 \\
\hline Kaingang & 0.0087 & 0.0004 & 0.0179 & 0.0014 & 0.0000 & 0.0000 \\
\hline
\end{tabular}

\subsection{Lexical Similarities II: Sound Correspondences}

Additionally, the Kaingang languages were compared with the geographically "closest" Polynesian languages, using the standard 
methods of historical linguistics. Over 40 lexical similarities were noted which remarkably obeyed regular sound correspondences. Table 1 provides some illustrations.

Table 1. Putative Cognates in Kaingang and Polynesian

\begin{tabular}{|c|c|c|c|c|}
\hline & \multicolumn{2}{|c|}{ Kaingang family } & \multicolumn{2}{|c|}{ Polynesian family } \\
\hline Glosses & Xokleng & Kaingang & Maori & Hawaiian \\
\hline 1. be same/alike & halike & hã ri ke & whārite & hālike \\
\hline 2. be same/alike & like & rike & rite & like \\
\hline 3. prefix & $h a-$ & $h \tilde{a}-$ & $w h \bar{a}-$ & $h \bar{a}-$ \\
\hline 4. breathe & & $h \tilde{a}-m h \tilde{a}-m$ & $h \bar{a} h \bar{a}$ & $h \bar{a} h \bar{a}$ \\
\hline 5. near & & kakã & tata & kaka \\
\hline 6. dig & & $k \tilde{o} k \tilde{o}-m$ & $k \bar{o} k \bar{o}$ & $P \bar{O} \bar{O}$ \\
\hline 7. sun & la & $r \tilde{a}$ & $r \bar{a}$ & $l \bar{a}$ \\
\hline 8. day & la & kurã & $r \bar{a}$ & $l \bar{a}$ \\
\hline 9. light/glow & kulay & kurã & kura & Pula \\
\hline 10. cloth & kulu & kuru & [huru] & hulu \\
\hline 11. blanket & kulu & kuru & [huru] & huluhulu \\
\hline 12. kind & kulu & & & hulu \\
\hline
\end{tabular}

The words in Table 1 obey the following regular sound correspondences (2), listed in the order: Xokleng/Kaingang/Maori/ Hawaiian, where the numbers on the right hand side indicate the items in Table 1 substantiating each sound correspondence. 
108 The Kaingang-Austronesian Relationship Hypothesis

(2) Some Sound Correspondences

\begin{tabular}{ll}
$\mathrm{X} / \mathrm{K} / \mathrm{M} / \mathrm{H}$ & Examples Nos. \\
\hline $\mathrm{h} / \mathrm{h} / \mathrm{wh} / \mathrm{h}$ & $1,3,4$ \\
$\mathrm{l} / \mathrm{r} / \mathrm{r} / \mathrm{l}$ & $1,2,7,8,9,10,11,12$ \\
$\mathrm{k} / \mathrm{k} / \mathrm{t} / \mathrm{k}$ & $1,2,5$ \\
$\mathrm{k} / \mathrm{k} / \mathrm{k} / \mathrm{i}$ & 6,9 \\
$\mathrm{k} / \mathrm{k} / \mathrm{h} / \mathrm{h}$ & $9,10,11$ \\
$\mathrm{a} / \tilde{\mathrm{a}} / \overline{\mathrm{a}} / \overline{\mathrm{a}}$ & $1,3,4,7,8$ \\
$\mathrm{a} / \mathrm{a} / \mathrm{a} / \mathrm{a}$ & 5,9 \\
$\mathrm{i} / \mathrm{i} / \mathrm{i} / \mathrm{i}$ & 1,2 \\
$\mathrm{e} / \mathrm{e} / \mathrm{e} / \mathrm{e}$ & 1,2 \\
$\tilde{\mathrm{o}} / \tilde{\mathrm{o}} / \overline{\mathrm{o}}, \overline{\mathrm{o}}$ & 6 \\
$\mathrm{u} / \mathrm{u} / \mathrm{u} / \mathrm{u}$ & $9,10,11,12$ \\
&
\end{tabular}

\subsection{Lexical Similarities III: Non-Random Sets}

The above lexical tests were supplemented by several dozens of other comparisons, which occasionally could be only slightly less regular, but served to reveal resemblances in both language families in various "non-random word sets," like synonyms, homonyms, paronyms, compound words, lexical fields, and so on, which are less likely to occur by mere chance and hence impart additional plausibility to the comparisons.

In addition to showing cognates explained by sound correspondences, the words in Table 1 are selected as to illustrate matches in some non-random word sets. Thus, comparisons 1-3 show a similarity between Kaingang $h a-(l / r) i k e$ and Polynesian $h a-$ $(l / r)$ ike in both lexicon and grammar (the prefix $h a$ - in both families having identical form and function in present context, and variously designated in the different languages: 'emphatic' (Xokleng), 'assertive' (Kaingang), and 'causal' (Polynesian)). Comparisons 7-9 show derivative words, viz. $(l / r) a$ and $k u(l / r) a$ in both families 
having coinciding meanings. Comparisons 10-12 show similar polysemous form $k u(l / r) u$ in both families in which the different meanings ('cloth,' 'blanket,' 'kind') also coincide, and importantly, the last of which, "kind," is a very "unusual" companion of the first two, and its concomitant coincidence is therefore significant. Pericliev $(2009,2010)$ discusses matches in various other nonrandom sets, including small lexical fields like body parts (11 comparisons), smaller numerals (5 comparisons), words connected with "water" (10 comparisons), and so on.

\subsection{Lexical Predictions}

Like every hypothesis, our hypothesis of Kaingang-Austronesian relationship may be tested by making predictions and testing these predictions against actual data. This general mode of reasoning takes a specific form in our test. I take a sequence of two words in Kaingang $<\mathrm{W} 1+\mathrm{W} 2>$, whose meaning as a whole, as well as the meaning of one of the constituent words, W1, is known, but that of the other, W2, is not, though W2 can be reasonably reliably predicted from context. This prediction, then, under the assumption that the Kaingang and Austronesian families are related, can be tested by seeing whether or not a correlative word in Austronesian exists with the appropriate predicted meaning. This reasoning mode mimics the real-life situation in which one tries to reconstruct the died-out meaning of a word in some language by reference to a related language that has preserved this word meaning.

By way of illustration, Kaingang ka rigri means 'small mosquito,' $k a$ in this context standing for 'mosquito.' The word rigri, however, is with unknown meaning and according to Wiesemann (personal communication) does not occur outside this word complex. Assuming a connection between Kaingang and Austronesian/ Polynesian, we can predict that if ringri designates 'small'-as it would follow from context - we could find a correlative in 
110 The Kaingang-Austronesian Relationship Hypothesis

Austronesian. Indeed, the formally similar riki means 'small' in Austronesian.

\subsection{Extra-Linguistic Data}

There is also extra-linguistic evidence speaking in favour of the Kaingang-Austronesian relationship hypothesis. First, genetically South America is the most diverse part of the world, and Central America is more similar to North America than to South America (Cavalli-Sforza et al. 1994: 339). Secondly, and more specifically, the Macro-Ge people, in drawing a phylogenetic tree of 23 American tribes, grouped according to linguistic criteria (CavalliSforza et al. 1994: 323-4), were found to be the worst outliers (with Macro-Tucanoans). Thirdly, and most importantly, apart from these more circumstantial, even if quite suggestive, pieces of genetic evidence that (at least some parts) of South America do not fit into the scenario of exclusively North-South population movementwhich is the prevalent current belief today-there emerged recently genetic work giving sound evidence for the predominantly SouthEast Asian and Oceanic origin of South American native populations. E.g., Ribeiro et al. (2003), analyzing the Macro-Gespeaking Xikrin and the Tupi-speaking Parakanã (note that Tupi is believed to be related to Macro-Ge), found them to be genetically similar to Indonesians and South-East Asian populations, concluding that "These results corroborate the existence of genetic affinities between Brazilian Indians and South-east Asian and Oceanic populations," their investigation being intended to "further contribute to the theory of a predominantly Asiatic origin of the American natives" (p. 59).

And, finally, an argument from Xokleng's beliefs. According to Henry (1941: 127) "The Kaingang [i.e., the Xokleng] have a clear idea of a period long ago when a number of events happened: their ancestors came out of the sea and over the mountains to the west..." 
[italics mine].

Despite the breadth of the data used to corroborate the link between the Kaingang and the Austronesian language families in previous research, the seeming implausibility of such an affinitylinking languages separated by vast geographical distancesrequires more in-depth analyses to be provided in both lexicon and grammar in order to provide firmer evidence. Indeed, a detailed illustration of similarities within a limited domain like say lower numerals or kinship yields higher subjective probability than displaying less detailed resemblances argued for random words. The goal of this paper is to elaborate and expand our previous analysis of kinship vocabulary data, and thus provide compelling arguments for the affinity previously hypothesized. There are a number of reasons for exploring particularly kinship vocabularies. The first is that they are as a rule the best studied lexical domain in the world languages, and the language families at issue are no exception. The second reason is the uniquely systematic nature of kinship terms, allowing their precise meaning representation and hence comparison. The third reason is that both the semantic and formal structure of kinship terms are relatively stable over time, and resistant to borrowing. The fourth reason is the closed nature of kinship vocabularies, diminishing the possibility for linguists to be misled by mere chance in the comparisons. And last but not least, the anthropological patterning of kin terms imparts an additional socio-cultural level of evidence, over and above the purely linguistic one.

\section{Comparisons of Kin Terms}

There are various papers on the Kaingang family kin terms. Below I list data from the standard sources: Henry (1941; cf. also Henry 1935, 1948) for Xokleng and Wiesemann (1972, 1974; cf. also Wiesemann 1978) for Kaingang. 
112 The Kaingang-Austronesian Relationship Hypothesis

Table 2. The Usual Abbreviations for Kin Types

\begin{tabular}{|l|l|l|}
\hline $\mathrm{F}=$ father & $\mathrm{M}=$ mother & $\mathrm{Z}=$ sister \\
\hline $\mathrm{B}=$ brother & $\mathrm{H}=$ husband & $\mathrm{W}=$ wife \\
\hline $\mathrm{Sb}=$ sibling & $\mathrm{GF}=$ grandfather & $\mathrm{GM}=$ grandmother \\
\hline $\mathrm{y}=$ younger & $\mathrm{e}=$ elder & $\mathrm{m} . \mathrm{s} .=$ male speaker \\
\hline
\end{tabular}

\subsection{Xokleng Kinship Terms}

(3) a. yug, F, GF; all males much older than ego; men who have had relations with ego's $\mathrm{M}$

b. ñ̃, M, GM; all females much older than ego; women who have had relations with ego's $\mathrm{F}$

c. kokla, ceremonial $\mathrm{F}$; often used as a courtesy term; man who treats ceremonially umbilical cord, and who assists in the piercing of the lip of a boy and the thigh of a girl

d. $m \varepsilon$, ceremonial $\mathrm{M}$, woman who treats ceremonially umbilical cord, and who assists in the piercing of the lip of a boy and the thigh of a girl

e. kake, relation; cousins of all classes; rarely aunt, never B or $\mathrm{Z}$; courtesy term for people not related by blood

f. yawi, all people somewhat younger than ego

g. nuynen, $\mathrm{Sb}$; all blood relatives excepting real parents and grandparents; all members of the extended family

h. plü, W; women with whom a male ego has had sexual relations; women with marks different from a man, and therefore potential sexual partners/wives

i. men, $\mathrm{H}$; men with whom female ego has had sexual relations; men with marks different from a woman, and therefore potential sexual partners/husbands

j. yomle, all blood relatives of $\mathrm{H}$ or $\mathrm{W}$

k. $y i$, child; all people very much younger than ego, and the 
children of all people ego has had sexual relations with

1. klã, offspring

m. koi $k a h \varepsilon$, family, tribe, people with the same design

n. $p$, birth

\subsection{Kaingang Kinship Terms}

(4) a. $y \supset g, F, F B, F F$

b. $n \tilde{\partial}, \mathrm{M}, \mathrm{MZ}$

c. kakrã, WF, MB, ZH; an old man from opposite moiety

d. $m \varepsilon, \mathrm{FZ}, \mathrm{WM}$

e. $k a \tilde{k} e$, elder $\mathrm{Sb}$

f. yãwi, younger $\mathrm{Sb}$

g. we, $\mathrm{Z}$ m.s.

h. [nũynin], navel; not listed as kinterm

i. $p r \tilde{u}, \mathrm{~W}$

j. $m \varepsilon n, \mathrm{H}$

k. yamre, MBS, FZS, ZH, WB

1. kosin, sĩ, child

m. $k r \tilde{e}$ (or $k r \tilde{a})$, offspring

n. kankã , family, tribe

Table 3 supplements these kin terms with several comparative wordlists (Quadros 1889, Adam 1902, Vogt 1904, Hanke 1947) for various Kaingang vernaculars. The data for the Austronesian family in the table basically comes from (Blust 1993, 1995; Biggs \& Clark 2006; the Austronesian Basic Vocabulary Database).

Table 3 lists apparently cognate words in the two families. The Kaingang family words are compared with reconstructed (asterisked “*”) Proto-Polynesian (PPn) forms or with reconstructed (doubleasterisked “**”) forms from earlier historical stages of the language (Proto-Oceanic (POc), Proto-Malayo-Polynesian (PMP)) that must have been retained in the Austronesian language immediately 
114 The Kaingang-Austronesian Relationship Hypothesis

ancestral to the Kaingang family. These reconstructions may be accompanied-for reasons of clarifying the connection with Kaingang - by a word from a specific language, which is necessarily a reflex of, or derived from (notated as " $<$ "), the reconstructed form. These words, with the languages to which they belong, are listed in a note to Table 3.

Some seeming formal discrepancies of the Kaingang words in comparison to their Austronesian correlatives are explained by the following phonological processes:

(5) a. The penultimate vowel in bi-syllabic and tri-syllabic Austronesian words is elided in Kaingang, thus reducing the number of syllables in the corresponding Kaingang words. Examples of the process in Table 3 are Nos. 2, 3, 4, 5, 9, 13, 15, 16, 17, 19, 21.

b. The Austronesian open vowel $a$ corresponds variously to open (mid) vowels $a, \varepsilon$, , ә (and occasionally to e) in the various Kaingang dialects.

c. The PMP consonant $b$ (=POc $p$ and $\mathrm{PPn} f$ ) may correspond to $\mathrm{k}$ in Kaingang, cf. No. 20. ${ }^{1}$

Table 3. Putative Kin Term Cognates in the Kaingang and Austronesian Language Families

\begin{tabular}{|c|c|c|c|c|}
\hline \multirow{2}{*}{ Glosses } & \multicolumn{3}{|c|}{ Kaingang family } & \multirow{2}{*}{$\begin{array}{l}\text { Austronesian } \\
\text { family }\end{array}$} \\
\hline & $\begin{array}{l}\text { Xokleng } \\
\text { (Henry) }\end{array}$ & $\begin{array}{l}\text { Kaingang } \\
\text { (Wiesem.) }\end{array}$ & $\begin{array}{l}\text { Other Kaing. } \\
\text { vernaculars }\end{array}$ & \\
\hline 1. father/ancestor & yuy & $y \supset \eta$ & ion, io & $\begin{array}{l}y a \eta \\
(<* * \text { qian })\end{array}$ \\
\hline 2. mother & jก̃ & $n \tilde{a}$ & $n a$, ла & $\begin{array}{l}* * \text {-ina } \\
(* * n a \text { 'vocative') }\end{array}$ \\
\hline
\end{tabular}

1 As another example of this sound change, cf. PMP **bulu, POc **pulu, Pn *fulu

= Xokleng kulu, Kaingang kuru 'coarse hair, cloth; colour.' 


\begin{tabular}{|c|c|c|c|c|}
\hline \multirow{2}{*}{ Glosses } & \multicolumn{3}{|c|}{ Kaingang family } & \multirow{2}{*}{$\begin{array}{l}\text { Austronesian } \\
\text { family }\end{array}$} \\
\hline & $\begin{array}{l}\text { Xokleng } \\
\text { (Henry) }\end{array}$ & $\begin{array}{l}\text { Kaingang } \\
\text { (Wiesem.) }\end{array}$ & $\begin{array}{l}\text { Other Kaing. } \\
\text { vernaculars }\end{array}$ & \\
\hline 3. mother & & $y \tilde{z}$ & $y a$ & **aya \\
\hline 4. aunt & mә & mә & $m a$ & **ema \\
\hline 5. uncle/old man & kokla & $k a k r a \tilde{~}$ & kakara & $\begin{array}{l}\text { kakara } \\
(<* \text { ko-koro })\end{array}$ \\
\hline 6. elder sibling & kake & kãke & & **kaka \\
\hline 7. younger sibling & yawi & $y \tilde{a} w \dot{\boldsymbol{t}}$ & & $\begin{array}{l}\text { yari } \\
(<* * \text { huanji) }\end{array}$ \\
\hline 8. younger sibling & & & enri & $\begin{array}{l}\text { eri, andi } \\
(<* * \text { huanji) }\end{array}$ \\
\hline 9. younger sibling & & & $r i-n$ & $\operatorname{ari-n}(<* *$ huanji $)$ \\
\hline 10. younger sibling & & & hari & $\begin{array}{l}\text { hari } \\
(<* * \text { huanji) }\end{array}$ \\
\hline 11. younger sibling & & & engi & $\begin{array}{l}\text { aygi } \\
(<* * \text { huanji) }\end{array}$ \\
\hline $\begin{array}{l}\text { 12. sister } \\
\quad \text { (male speaker) }\end{array}$ & & we & we & $\begin{array}{l}\text { we } \\
(<* \text { weka or kawe })\end{array}$ \\
\hline 13. wife & plũ & prũ & & ${ }^{* *} \mathrm{p}^{w} \mathrm{p}^{w}$ úlú \\
\hline 14. husband & $m \varepsilon n$ & $m \varepsilon n$ & man & $\begin{array}{l}\operatorname{man} \\
(<* * \text { ma-Ruqanay })\end{array}$ \\
\hline 15. family & $m l \varepsilon$ & $m r \varepsilon$ & mre & *more \\
\hline 16. child/small & $y i($ or $t f i)$ & {$[k J-] \int i-n$} & $t f i, \int i, t i$ & $\begin{array}{l}\text { jii, sisi, iti } \\
(<* * \text { itik })\end{array}$ \\
\hline 17. offspring & $k l a ̃$ & $k r \tilde{e}($ or $k r \tilde{a})$ & & **akaRa \\
\hline 18. tribe & $k \supset i k a$ & kankã & kaika & $\begin{array}{l}\text { kaika } \\
(<* \text { kāiga })\end{array}$ \\
\hline 19. ancestor & po & & & **apu \\
\hline $\begin{array}{l}20 . \text { youth/ } \\
\text { young man }\end{array}$ & kalu & kĩru & kelu-m & $\begin{array}{l}\text { baru, beru } \\
(<* * \text { baqeRu) }\end{array}$ \\
\hline
\end{tabular}


116 The Kaingang-Austronesian Relationship Hypothesis

\begin{tabular}{|c|c|c|c|c|}
\hline \multirow[b]{2}{*}{ Glosses } & \multicolumn{3}{|c|}{ Kaingang family } & \multirow{2}{*}{$\begin{array}{c}\text { Austronesian } \\
\text { family }\end{array}$} \\
\hline & $\begin{array}{l}\text { Xokleng } \\
\text { (Henry) }\end{array}$ & $\begin{array}{l}\text { Kaingang } \\
\text { (Wiesem.) }\end{array}$ & $\begin{array}{c}\text { Other Kaing. } \\
\text { vernaculars }\end{array}$ & \\
\hline 21. male/penis & & $\eta r \varepsilon$ & yra & $\begin{array}{l}\text { *kala } \\
(<* * \text { ykala })\end{array}$ \\
\hline 22. female/vagina & & $\Phi u$ & $f u$ & $* f \bar{u}$ \\
\hline
\end{tabular}

NOTE: Words from specific Austronesian languages quoted in Table 3: yay (Old Javanese), kakara (Maori), yari (Wetan), eri (Kambera), andi (Wolio), ari-n (Solorese), hari (Ata Manobo), aygi (Toba Batak), we (Loniu), man (East Damar), jii (Tongan), sisi (Aniwan), iti (Maori), baru (Malay), beru (Lamboya), kaika (Maori, South Island dialect).

The following remarks are intended to supplement and clarify some aspects of Table 3, and use numeration corresponding to that in Table 3.

(6) a. No.1 father/ancestor: Xokleng yun 'father, grandfather; all males much older than ego,' Kaingang yon 'father, father's

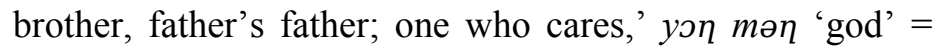
PMP **qian 'ancestor, deity, divinity,' Old Javanese yan 'god, goddess; person dedicated to the sacred'; cf. also Polynesian forms like Hawaiian io 'forunner,' Maori, Mangaian io 'god' matching some Kaingang dialects having io 'father.'

b. No.3 mother: PMP **aya is usually reconstructed as 'father's sister,' but Blevins (2007) reconstructs also 'mother.'

c. No.4 aunt: The words glossed as 'aunt' in Table 2 more specifically mean 'father's sister' in both the Kaingang and Austronesian families, 'mother's sister' being covered by the words for 'mother.'

d. No.5 uncle/old man: The old Polynesian form *koro (reduplicated kokoro) means 'father, old man,' e.g., Maori having corresponding forms both with this form with $o$, and such 
with $a$, viz. kara, kakara. The Kaingang language word kakrã has both a kinship denotation (uncle, mother's brother), and a non-kinship denotation, meaning 'an old man from the opposite moiety,' and the corresponding Xokleng word kokla means 'ceremonial father,' who is actually the mother's brother in the ritual of cutting the umbilical cord of the child.

e. No.6 elder sibling: The seeming disagreement between the Kaingang family forms kake/kãke and the PMP **kaka in the last vowel is observed also in other Austronesian languages like Manggarai, Endeh, as observed by Blust (1993).

f. No.15 family: The Polynesian word *mole reconstructed as 'taproot' is figuratively extended in the Kaingang family to mean 'family,' as e.g., in Hawaiian mole 'foundation, source, cause; ancestral root, family.' The Xokleng kinship term $y$ o- $m l \varepsilon$ 'all blood relatives of husband or wife' and Kaingang ya-mre 'mother's brother's son, father's sister's son, sister's husband, wife's brother' (not appearing in Table 3) are compounds literally meaning 'mother's root, family' (as registered by Val Floriana 1920).

g. No.17 offspring: The POc word **akaRa 'root' is figuratively extended in the Kaingang family to mean 'offspring,' as e.g., in Hawaiian $a ? a$ 'small root, rootlet; fig. womb, offspring.' Additional evidence for this meaning transfer having taken place in Kaingang is the presence in the language of the same form $k r \tilde{e}$ (or $k r \tilde{a}$ ) designating the bamboo plant criciuma.

h. No.18 tribe: The Polynesian word *kāiga is often analysed as $k \bar{a} i$ 'people of a place' + nga 'nominalizing suffix.' The separate rendering of the correlative Xokleng word $k o i k a$ suggests a similar division of the Kaingang family words; additionally, there is a Kaingang correlative word kai with the meaning 'person, man,' just as in Polynesian. 
118 The Kaingang-Austronesian Relationship Hypothesis

The comparison of the kin term domain shows remarkable similarities between the Kaingang and the Austronesian families both in terms of number of matching words and in terms of the closeness of the formal matches and thus provides very strong evidence in support of the Kaingang-Austronesian relationship hypothesis at issue.

\section{Comparisons of Kin Term Patterns}

Kinship terminology of languages can be compared not only by reference to the forms (shapes) of kin terms, but also by reference to their semantic structuring in so-called "kin term patterns." Kin term patterns show, for all kinsmen (grandparents, grandchildren, uncles, aunts, siblings, cross-cousins, and so on) the number of kin terms used for that kin as well as their range of reference, based on their formal underlying structure of discriminations such as sex of referent (male/female), relative age (elder/younger), sex of the connective relative, sex of speaker, and so on. By way of illustration, two examples for the kin grandparent are the "Bisexual Pattern" (having two terms, distinguished by sex, which can be glossed as "grandfather" and "grandmother"), the "Merging Pattern" (having a single undifferentiated term, which can be glossed as "grandparent"). The establishment of kin term patterns and their distribution in the world languages has been a major concern of anthropologists over the years. A major contribution to this trend is the collection of kin term patterns of 566 societies by Murdock (1970). This collection is based on over 1000 kinship systems and is representative of all world languages. Murdock's database describes eight relatives (or kin types), viz. grandparents, grandchildren, uncles, aunts, nephews, and nieces, siblings, cross-cousins, and siblings-in-law, which are described in terms of a total of 192 patterns. 
I have used Murdock's dataset in two experiments having to do with the hypothesis of Kaingang-Austronesian link.

\subsection{A Statistical Test}

In the first experiment (Pericliev 2007), this database was computationally explored with the goal of finding statistically significant similarities in kin term patterns between pairs of societies speaking languages belonging to "different" language families according to the standard language classification source Ethnologue. The idea was to find what languages show non-chance pattern similarities with language families others than those with which they are currently grouped, or, in other words, to find eventual misclassifications. The statistical test was a "permutation test," involving the comparison of the probability of the occurrence of the matching patterns in a pair of languages in the original data with this probability in randomized data, obtained by 1000 permutations of the original data.

The pair-wise society comparison revealed that Xokleng (the language representing the Kaingang family in the database) had 7 matching kinship patterns with the Amis (Taiwan) and 6 matching kinship patterns with both the Chuukese (Micronesia) and the Ulithian (Micronesia). These were the most significant results in comparison to all other investigated society pairs, at levels of $\mathrm{p}=$ $0.005, \mathrm{p}=0.002$, and $\mathrm{p}=0.008$, respectively. Xokleng thus turned out to follow an Austronesian type of kinship patterning, showing also substantial kin term pattern overlaps with other Austronesian languages like Rotuman, Samoan, and Maori. Checking the original files for Xokleng of the contributor of the database, anthropologist G. P. Murdock, showed that he had marked the structural type of Xokleng's terminology as "Normal Hawaiian," which is characterised by a generational-terminology structure for the parental generation, and in which there is no distinction between siblings and cousins, all 
called by the term for sibling. Further details can be found in Pericliev (2007: 42-48).

The Kaingang language was not included in Murdock's database, intentionally excluding data on some societies in order to evade repetitions, but it similarly revealed (nearly statistically significant) kin term pattern overlaps with the Austronesian family. In effect, this test furnished a further corroboration of the KaingangAustronesian relationship hypothesis at least insofar as kinship semantic patterning is concerned.

\subsection{A Test with Language Family Profiles}

In the second experiment, Murdock's collection of kin term patterns, grouped into language families, was used in another fashion. A sophisticated computer program was employed to profile the language families, so that each language family was distinguished in terms of kin term patterns from all others in the most parsimonious way. The discovered language family profiles revealed that kin term patterns may be considered as strong indicators of genetic affiliation, the patterns for siblings, their spouses and their children being the best predictors of affiliation. A number of hypotheses regarding language family membership were evaluated in the light of the discovered language family profiles, including those of the Kaingang family (for details, cf. Pericliev 2011).

The general idea was to see with which of the 64 language family profiles of patterns, inspected in the book, the Kaingang languages fitted best. It turned out that the Kaingang family fitted best with the Austronesian family and only second best with the Macro-Ge family, with which they are currently associated. Thus, the MacroGe family has a profile comprising 6 patterns that distinguish the family from all other families, and the Kaingang languages fail to match 2 of these 6 patterns, while Austronesian has a profile of 9 
patterns and the Kaingang languages fail to match only 1 of these 9 patterns, the failed Kaingang pattern, besides, being apparently just an evolutionary version of its Austronesian prototype (cf. Pericliev 2011: 146-148).

This test, again, provides support for the existence of a linguistic link between Kaingang and Austronesian.

\section{Discussion}

The similarities between the Kaingang and the Austronesian language families should be explained. There exist three potential reasons: (i) chance coincidences, (ii) contact and borrowing (diffusion), or (iii) genetic affinity.

The first potential reason could safely be ignored, because: (i) the formal resemblances revealed in kinship vocabulary apparently exceed chance; (ii) the related semantic similarities in kin term patterns were shown to be statistically significant; and (iii) our previous investigations, including also computations of probabilities in 100-item basic vocabulary comparisons, point in the same direction.

The second potential reason, borrowing, also seems unlikely, for: (i) no previous contact between Kaingang and Austronesian peoples is documented, and it is unlikely that Austronesian lexicon and structural features could be borrowed in Kaingang via Portuguese, German or French, who are known to have had more recent contacts with both Austronesian and Kaingang people; (ii) the witnessed borrowing of basic vocabulary like kinship terms, including the borrowing of "non-random word sets" (synonyms, polysemous or homonymous words, and so on) as well as structural features is evident to an extent that is hard to believe to have happened even after a lasting contact situation; (iii) if we assume borrowing, then the fact that practically all kinship words in Kaingang have 
Austronesian correlatives, and the fact that Kaingang has presently two kinship systems, one with only Kaingang, and the other with mixed Kaingang and Portuguese words (Wiesemann 1974), would lead to the apparently highly unlikely situation in which a language uses two borrowed kinship systems, with no trace whatsoever of its original (native) words.

The only alternative explanation that remains therefore is genetic affiliation, which is also difficult to explain, taking into consideration the immense distance between present-day Austronesian and Kaingang populations. Indeed, how could have Austronesians (assuming that Kaingang is an Austronesian language, which our data point to) reached the Atlantic parts of Brazil? We have no answer to this question, and will have to suffice with some remarks.

(7) It is unlikely that Austronesians have reached Brazil via the Atlantic ocean, e.g., from Africa and Madagascar from where major slave routes in $16^{\text {th }}$ and $17^{\text {th }}$ centuries are documented, because our preliminary investigations do not show Kaingang to be most closely resembling Austronesian languages spoken in Madagascar.

(8) We are not in a position, at this stage of our investigations, to determine precisely the exact position of Kaingang (assuming its Austronesian membership) into the Austronesian language family, but its membership into its Oceanic branch seems plausible. One reason for this is that the discussed kinship data e.g., contains innovations in Proto-Oceanic, or later language groupings (Pawley 2007: 38), which seem to have reflexes in the Kaingang family. 
Table 4. POc (or Later) Terms in Kaingang without Known Antecedents in $\mathrm{PMP} / \mathrm{PAn}$

\begin{tabular}{|l|l|l|}
\hline POc (or later branch) & English & Kaingang \\
\hline$*$ kainaya & lineage, descent group & $k a n k \tilde{a}$ \\
\hline$* k a i$ & person of the place & $k a i$ \\
\hline$*$ mwaqane & man, male & $m \varepsilon n$ \\
\hline $\begin{array}{l}\text { more } \\
\text { (Central-East. Polynesian) }\end{array}$ & taproot, family & $m r \varepsilon$ \\
\hline ko-koro (East Polynesian) & old man, father & kakrã \\
\hline
\end{tabular}

These lexical data, alongside with other grammatical innovations of Oceanic (as e.g., the presence of prenasalized voiced consonants, preference for open syllables, phonological reduction processes, and so on) that are present in Kaingang, suggest an Oceanic origin of Kaingang, and hence probably trans-Pacific contact with South America.

\section{Conclusions}

In this paper, I presented kinship terminology data in support of the hypothesis for the existence of a linguistic (probably genetic) link between the geographically distant Kaingang and Austronesian language families. Kinship terms, as is well known, are one of the best predictors of language affiliation and hence constitute a sound basis for historical comparison. I inspected various aspects of Kaingang and Austronesian kinship terminological systems, pertaining both to their form and their meaning (kin term patterns) and found apparently sound support for the hypothesis in either aspect. The data further indicates a probable Oceanic or later-branch 
124 The Kaingang-Austronesian Relationship Hypothesis

origin of Kaingang, but the determination of more exact positioning of Kaingang into the Austronesian family remains a major problem for future investigations.

\section{References}

Adam, L. 1902. Le parler des Caingangs. Congr. Intern. Americanistes 12, 318-330.

Austronesian Basic Vocabulary Database. Available at URL $<$ http://language.psy.ayckland.ac.Nz/austronesian/>.

Biggs, B. \& R. Clark. 2006. POLLEX: Comparative Polynesian Lexicon [Computer Data Base]. University of Auckland.

Blevins, J. 2007. A Long Lost Sister of Proto-Austronesian? ProtoOngan, Mother of Jarawa and Onge of the Andaman Islands. Oceanic Linguistics 46, 154-198.

Blust, R. 1993. Austronesian Sibling Terms and Culture History. Bijdragen tot de Taal-, Land- en Volkenkunde 149, 22-76. . 1995. Austronesian Comparative Dictionary [Computer Files]. University of Hawaii.

Cavalli-Sforza, L. et al. 1994. The History and Geography of Human Genes. Princeton, NJ: Princeton University Press.

Davis, I. 1966. Comparative Jê Phonology. Estudos Lingüísticos 1, $10-24$.

Hanke, W. 1947. Apuntes sobre el idioma Caingangue de los Botocudos de Sta. Catarina, Brasil. Arquivos do Museu Paranaense 6, 6197.

Henry, J. 1935. A Kaingang Text. International Journal of American Linguistics 8, 172-218.

. 1941. Jungle People: A Kaingáng Tribe of the Highlands of Brazil. New York: J. J. Augustin.

. 1948. The Kaingang Language. International Journal of American Linguistics 14, 194-204. 
Klamer, M. 2002. Typical Features of Austronesian Languages in Central/Eastern Indonesia. Oceanic Linguistics 41, 363-383.

Murdock, G. 1970. Kin Term Patterns and their Distribution. Ethnology 9, 165-207.

Oswalt, R. 1991. A Method for Assessing Distant Linguistic Relationships. In S. Lamb \& E. Mitchell (eds.), Sprung from Some Common Source: Investigations into the Prehistory of Languages 389-404. Stanford, CA: Stanford University Press.

Pawley, A. 2007. The Origins of Early Lapita Culture: The Testimony of Historical Linguistics. In S. Bedford et al. (eds.), Oceanic Explorations: Lapita and Western Pacific Settlement 17-50. Canberra: ANU E Press.

Pericliev, V. 2006. Significant Lexical Similarities between a Language of Brazil and Some Languages of Southeast Asia and Oceania. Journal of Universal Language 7.2, 121-145.

. 2007. The Kaingang (Brazil) Seem Linguistically Related to Oceanic Populations. Journal of Universal Language 8.2, 3959 .

.2009. Kaingang and Austronesian-Similarities between Geographically Distant Languages. Current Issues in Unity \& Diversity of Language. Papers Selected from $18^{\text {th }}$ Intl Congress of Linguists 875-892.

. 2010. Machine-Aided Linguistic Discovery: An Introduction and Some Examples. London \& Oakville: Equinox.

. 2011. Profiling Language Families by their Kin Term Patterns: A Computational Approach (LINCOM Etymological Studies $I I)$. Muenchen: Lincom GmbH.

Quadros, F. 1889. Memoria sobre os trabalhos de exploração e observaзго efetuada pela secção da comissão militar encarregada da linha telegráfica de Uberaba a Cuiabá, de fevereiro a junho de 1889. Revista do Instituto Historico e Geografico Brasileiro 55, 233-260.

Ribeiro, D. et al. 2003. Haplotypes of $\alpha$-Globin Gene Regulatory 
126 The Kaingang-Austronesian Relationship Hypothesis

Element in Two Brazilian Native Populations. American Journal of Physical Anthropology 121, 58-62.

Rodrigues, A. 1999. Macro-Jê. In R. Dixon \& Y. Alexandra (eds.), The Amazonian Languages 164-206. Cambridge: Cambridge University Press.

Val Floriana, M. 1920. Diccionarios Kainjgang-Portuguez e Portuguez-Kainjgang. Revista do Museu Paulista 12, 1-392.

Vogt, F. 1904. Die Indianer des Obern Paraná: II. Die Indianer der Coroados-Gruppe. Mitteilungen der Anthropologischen Gessellschaft in Wien 34, 353-377.

Wiesemann, U. 1972. Die phonologische und grammatische struktur der Kaingáng-Sprache. The Hague: Mouton.

. 1974. Time Distinctions in Kaingáng. Zeitschrift für Ethnologie 99, 120-30.

. 1978. Os dialetos da língua Kaingáng e o Xokléng. Arquivos de Anatomia e Antropologia 3, 197-217. 